\title{
Ecocides as a Serious Human Rights Violation: A Study on the Case of River Pollution by the Palm Oil Industry in Indonesia
}

\author{
Joko Setiyono*, Aga Natalis \\ Faculty of Law, Universitas Diponegoro, Jalan Prof. Soedarto, S.H., Semarang 50275, Indonesia
}

Corresponding Author Email: jokosetiyono@ lecturer.undip.ac.id

https://doi.org/10.18280/ijsdp.160807

Received: 28 September 2021

Accepted: 23 November 2021

\section{Keywords: \\ serious human rights violations, ecocides, river pollution, palm oil companies, environmental law}

\begin{abstract}
This study aims to analyse ecocides as a gross violation of human rights through a case study of river pollution conducted by palm oil companies in Indonesia. This article is methodologically distinctive from doctrinal legal research, primarily through a literature review. There are three main reasons for incorporating environmental concerns as an extraordinary crime of ecocide into serious human rights violations, especially those committed by several palm oil companies in Indonesia, namely: The quality of the Environment is the essence of human life that complements human dignity; environmental concerns and crimes in the tradition of extraordinary crimes are a response to the inability of national and even international environmental laws; and ensure restitution, rehabilitation and compensation to all victims of ecocide crime.
\end{abstract}

\section{INTRODUCTION}

Oil palm plantations hurt the ecosystem function of production forests or secondary forests [1]. Land clearing and draining of peatlands in converting forest to oil palm produce carbon dioxide emissions. Oil palm can indeed absorb carbon dioxide and oil potential to substitute fuels, but the use of biodiesel is still not able to compensate for the carbon emissions caused by forest conversion for oil palm plantations [2]. On the other hand, chemical substances for fertilisers, pesticides, and insecticides are directly responsible for the decline in water quality and aquatic habitats [3].

Based on a study conducted by Rasmus Kløcker Larsen and Tom Gill, there are several crucial issues related to water pollution by the palm oil industry, including water turbidity as a result of land clearing; poisons due to the use of pesticides, a decrease in the population of fish and aquatic plants; PalmOil Mill Effluent (POME) and other waste from oil palm either released directly into rivers or stored which will overflow during the rainy season; reducing or diverting the flow of water used for the process of drying and irrigating land; deforestation that can increase the risk of flooding in the area around the plantation, especially the risk of flash floods in the rainy season; draining of community land directly adjacent to plantations involves lowering the water level affecting wells, forcing villagers to leave traditional rice farming to work in palm oil production [4].

Indonesia faces extraordinary environmental challenges in global warming, pollution, loss of biodiversity, deforestation, agrarian conflicts and degradation of natural services [5]. The ecological crisis is getting worse every day, which is likely to worsen if the government has no serious effort to deal with it. The exploitation of natural resources will threaten the security of human life faster than the restoration of natural ecosystems [6].

In 2019, the Indonesian Forum for the Environment released several environmental damages and ecological disasters in Indonesia. That $86 \%$ of environmental damage, agrarian conflicts and ecological disasters stem from inequality over natural resources. The exploitation of natural resources comes from legal activities or obtaining permits from the government [7].

In this case, the corporation is suspected of being the leading actor for not complying and ignoring the prevention of environmental damage because it prioritises expansion and profit [8]. Therefore, environmental issues are only considered administrative arrangements and sanctions in the form of warnings, coercion, suspension or revocation of permits as regulated in Law No. 32 of 2009 concerning Environmental Protection and Management [9].

In the Indonesian environmental regime, environmental crimes are only administrative, civil and criminal offences. Environmental crimes in Indonesia have led to ecocides, namely, a systematic and massive crime against the Environment, having a broad and long-term impact and causing the peace and security of human life to be threatened.

Several researchers have researched ecocides, for example, the Research of Polly Higgins and his colleagues in 2013 [10]. The study entitled "Protecting the Planet: A Proposal for a Law of Ecocide" aims to record several examples of crimes and catastrophic losses. Environment and human and non-human species and various forms of response have called for models of justice and law that are more effective and appropriate than currently prevail. Research conducted by Martin Crook and Damien Short in 2014 [11]. The research, entitled "Marx, Lemkin and the Genocide-Ecocide Nexus", aims to encourage genocide scholars to attempt a paradigm shift in the greatest traditions of science and integrate the synthesis of genocide sociology and sociology environment to a theoretical apparatus that can illuminate the relationship between, and uncover the drivers of, ecocide and the social death of genocide. Research conducted by Lidgren [12]. The research 
entitled "Ecocide, Genocide and the Disregard of Alternative Life-Systems" aims to focus on articulating the importance of the international crime of ecocide, which can prosecute perpetrators for acts of ecocide as well as physical and cultural genocide. This includes the jurisdiction of the International Criminal Court (ICC). Research conducted by Prakasa [13]. The research entitled "Ecocide Crimes \& Omnibus Law: Review of International Law and its Implications on Indonesia Law", this research focuses on the draft legislation on the Omnibus Law on Job Creation, which a number of the article has the potential to remove the protection of rights, to repress the human rights of citizens, especially those related to civil and political rights as well as economic, social and cultural rights, as well as regarding law enforcement for weak environmental destroyers.

The basic assumption of this research is that environmental law in Indonesia has not yet adopted the concept of ecocide as a serious human rights violation, which is because the law is still weak from economic problems. Therefore, it is important to research ecocides as serious human rights violations in reforming the environmental law system in Indonesia. This research was conducted using non-doctrinal legal research methods (in detail in the methodology section).

Although both use the topic of ecocides, this study focuses more on analyzing ecocides as a serious human rights violation through a study of river pollution conducted by palm oil companies in Indonesia.

\section{METHODOLOGY}

This article ontologically describes ecocide as a gross violation of human rights through an analysis of crimes against palm oil companies in the environmental sector in Indonesia. Thus, this article is methodologically distinctive with doctrinal legal research, primarily through a literature review to find various secondary data in the form of primary legal materials and secondary legal materials related to the topics discussed in this article.

The purpose of choosing a doctrinal legal research approach is for the law to be recognized as an objective reality contained in the law. Through this doctrinal legal approach, it is hoped that various palm oil companies' ecocide schemes and motives in Indonesia can be revealed. It is hoped that these efforts will, in due course, contribute to a broad understanding of how ecocides should be recognized as a gross violation of human rights as an effort to tackle environmental crimes committed by palm oil companies in Indonesia.

The theory used in this study is the ecocide theory developed by Polly Higgins. For Higgins, ecocides are widespread and such damage that the enjoyment of peace by the territory's inhabitants has been or will be significantly diminished. An unlawful or delinquent act is committed with the knowledge that there is a high probability of severe and widespread or long-term environmental damage caused by the act [10].

\section{RESULTS AND DISCUSSION}

\subsection{Ecocides as serious human rights violations}

"Preventing environmental damage" over the past decade has become a sentence that is often encountered, either on social media, scientific articles, or other content [14]. Environmental damage cannot be considered as a small and local problem. However, it is a global problem, such as damage to the ozone layer, rising sea levels, depletion of the world's clean water stocks, and global warming [15]. The development of international criminal law in the last few decades shows a growing trend, and although many laws address certain behaviours (crimes), no law or treaty codifies environmental law or criminalises environmental destruction [16].

The ecological crisis that continues to occur and gets worse has finally triggered the emergence of ecocide [17]. The codification of ecocide as an international crime became a hot topic, in 2010 mainly by a lawyer from Scotland, Polly Higgins, who submitted an amendment to the Rome Statute to the International Law Commission, which included ecocide, which was defined as: "the extensive damage to, destruction of, or loss of ecosystem(s) of a given territory, whether by human agency or by other causes, to such an extent that peaceful enjoyment by the inhabitants of that territory has been or will be severely diminished" [10, 18].

Inhabitants, in the definition, are intended to protect not only humans living in the area but also to protect other species in the area. In his proposal, Higgins proposed the ecocide as the fifth crime against peace in the Statute Rome. The definition proposed by Higgins is described in a legal model which is described [12, 19]:

a. Acts or omissions committed in times of peace or conflict by any senior person within the course of State, corporate or any other entity's activity which cause, contribute to, or maybe expected to cause or contribute to ecological severe, climate or cultural loss or damage to or destruction of ecosystem(s) of a given territory, such that peaceful enjoyment by the inhabitants has been or will be severely diminished.

b. To establish seriousness, impact(s) must be widespread, long-term or severe.

This amendment states that ecocides are carried out by "senior persons" who threaten the peace or cause conflict at the state, corporate or other levels. This means that regulations will bind individuals, not entities or corporations; for example, a CEO of a palm oil company makes or does not prohibit policies that threaten the Environment, or a regional head approves permits mining that damage the environment. Unlike other international crimes, the proposed ecocide law does not require criminal intent; in other words, this crime is an absolute responsibility or strict liability [20].

Criminal acts that do not require this intention are characterised by the consequences of the action itself, such as releasing POME waste into rivers without proper treatment, which does not extend to damage the Environment, but the consequences of these actions disturb the peace of the "inhabitants" river and its surroundings. According to the definition proposed by Higgins, the action is categorised as ecocide. This can lead to a solution because the courts have not had criminal intent and cannot be found guilty by including mental elements. This absolute responsibility ensures that the company, through a "senior person", can be held responsible for actions that harm the Environment; in general, this absolute responsibility is imposed to prevent harmful actions, not to blame one or another party, so that corporate immunity can be undermined [21].

This legal model aims to protect peace, sustainability, and ecological sustainability. As a result, this law criminalises 
actions that disturb or damage these things. In the legal model proposed by Higgins, "inhabitants" are the biotic components of an ecosystem that include one or more: humans; animals; fish; birds or insects; plants; or other living things, so ecocide is a crime against living things, not just humans. However, in reality, this ecological peace can be caused by human action causing others, so the clause "Ascertainable vs Unascertainable" appears in the types of ecocides according to Higgins, Ascertainable is ecocide by humans. In contrast, Unascertainable is caused by natural factors, such as natural disasters. The legal model proposed by Higgins makes humans responsible for their actions and negligence, with the bottom line that these actions cause damage or loss to humans or nonhuman living things from an ecosystem [22].

This legal model categorises ecocide as "serious ecological, climate or cultural loss or damage to or destruction of ecosystem of a given territory(ies), such that peaceful enjoyment by inhabitants has been or will be severely diminished" [23]. The extent to which damage is stated as severe is a follow-up question in categorising ecological damage as ecocide; simply in that, the damage must have impacts far-reaching, long-term and severe. The three criteria for damage are adapted from the existing UN treaty; in article 1 of the Convention of Environmental Modification Techniques (ENMOD), broad impact means affecting an area on a scale of several hundred kilometres; long term, this means the damage lasts for months, or a season; while the weight itself involves a severe or significant disruption or endangering human life, nature, and resources economics or other assets. The Cambridge Dictionary has included the word ecocide in its dictionary since 2018, which is defined as "destruction of the natural environment of an area, or very great damage to it" [24].

This legal model is expected to be used as the fifth "core crime" in the Rome Statute, which regulates international crimes against humanity which in Article 5 states that the International Court of Crime has the right to deal with crimes that threaten the international community related to; the crime of genocide; crimes against humanity; war crimes; and the crime of aggression [25]. In the proposal that Higgings submitted to the UN Law Commission intending to amend the four major crimes in the Rome Statute, wherein his model, Higgins asked to make ecocide the crime against peace fifth. However, the proposal was rejected by several parties because they felt it would be challenging to implement, in addition to making the amendment required at least the approval of the 82 countries that have ratified the Rome Statute, coupled with the large number of countries that have ratified the statute, it will not be easy to reach an agreement to make an amendment. Plus each country has different geopolitical circumstances and legal systems; it is as simple as defining a crime to be difficult because of these circumstances [26].

Compared to making ecocide an international criminal crime under the Statute Rome, some experts prefer to use other alternatives to deal with environmental damage. The possible thing is to criminalise ecocides in the national sphere; by regulating ecocides in the national legal system, the problem of environmental damage will be handled appropriately because this is done based on natural rights where it is believed that nature and its contents also have the right to remain in a state peace-Guatemala as one of the countries that accommodate ecocide law and has an environmental court. Guatemalan courts have settled several cases in ecocide law until after a palm oil company polluted a river and killed river- dwelling fish, a village filed a lawsuit against the company in ecocide law in an environmental court. The case brought fresh air to the international community regarding handling cases of environmental destruction in ecocide law [27].

Talking about environmental law in Indonesia, ecocide is not used as a language to describe criminal acts that damage the Environment, a term to express acts in such a way known as environmental crimes or environmental offences. Environmental offences themselves have the meaning as an order or prohibition of the law on legal subjects which, if violated, are threatened with the imposition of criminal sanctions: imprisonment and fines to Protect the environment as a whole, as well as the elements contained in the Environment, both biotic and abiotic components. Such as animals, humans, land, water, and air. The environmental offence is formulated through Law Number 32 of 2009 concerning Environmental Protection and Management. All criminal provisions are formulated as long as the formulation of these provisions aims to protect the environment as a whole or the parts contained therein.

Environmental offences in the law contain the formulation of material and formal offences. The material offence contains offences or acts that are prohibited by law in which the act is deemed to have been fulfilled, resulting in a consequence, which is formulated in two categories of weighting: First, from the provisions of paragraph (1) of the article above, the weighting is related to causing injury to people and health hazards. Second, from the provisions of paragraphs (2), (3) of the article above, the weighting is in the form of actions that result in serious injuries or death. Furthermore, formal offences are offences or actions that are prohibited by law that is considered perfect or fulfilled once the act is carried out without requiring the act's consequences. In detail, the law on the protection of the environment and management contains 19 forms of actions or actions that can be subject to criminal sanctions. In this case, environmental criminal law in Indonesia is centred on the impact received by humans; this implies that Indonesian law has not recognised natural rights. Recognising natural rights is the first step in implementing ecocide law; at this point, Indonesia still has a long way to go in realising ecocide law.

Regarding the environmental destruction in Indonesia carried out by corporations, which in the Indonesian legal language based on the Indonesian Criminal Code only stipulates an individual (legal person) as the subject of a legal crime (legal person) [28]. Through the Indonesian Criminal Code, it is not possible to hold corporations accountable for environmental crimes. However, Article 398 of the Criminal Code states that individuals registered as managers or commissioners of a limited liability company, participating Indonesian airline or corporate association. Based on Indonesian legal principles, a corporation is a legal creation body, which consists of a "corpus", a physical element in which an "animus" element is added, making the legal entity have an element of personality. In declaring environmental crimes committed for and or on behalf of legal entities, at least it contains elements: Illegal acts of legal entities and their agents; whether a legal entity (as an individual legal person "legal person") or its representative as a perpetrator of a judicial crime, its actions depend on the crime committed, the rules, and the quality of evidence and prosecution; The motivation for crimes committed by legal entities is not only aimed at personal gain, but also at meeting needs and achieving organisational benefits. This motive may also be 
supported by operational norms (internal) and organisational subculture [29].

Determination of a legal entity as a perpetrator of environmental crimes in Indonesia can be carried out concerning the criteria for implementing tasks and achieving the objectives of the legal entity [30]. A legal entity is declared as a perpetrator if the action taken is proven to be carried out in the context of carrying out duties and or fulfilling the objectives of the legal entity, including its agents who are proven to have committed criminal acts on personal initiative and in contrast to the instructions given to them. Establishing a corporation as a legal subject (though not directly) and holding it accountable raises various pros and cons. The community's need for this is shown by the equality of humans and legal entities, assuming that corporations that commit environmental crimes can be held accountable, but in this scenario, the possibility of someone scapegoating for corporate negligence can occur [31]. This is done in the interest of releasing corporations from being responsible for environmental crimes; for example, a palm oil industry clears land by burning peatlands, but instead of taking direct responsibility, corporations can delegate the responsibility to agents who are ordered to do the burning [32].

The enactment of the Omnibus law in 2020 raises many question marks, especially in the Environmental cluster. Several provisions have changed with the enactment of the Omnibus law, including [33-35]:

1. The Omnibus law abolishes the provisions of article 40 of the law on environmental protection and management, where the article states matters relating to environmental permits, namely: "(1) Environmental permits are a requirement to obtain a business and activity license; (2) if the environmental permit is revoked, the business and activity permit is cancelled; (3) if the business and activity changes, the person in charge of the business and activity is obliged to renew the environmental permit.

2. Changes in the clause for administrative sanctions in the Omnibus law, previously in Article 76 paragraph (1) of the law on environmental protection and management stated: "Theminister, governor, or regent/mayor shall stipulate administrative sanctions to the person in charge of a business and/or activity if in the supervision it is determined that a violation of the environmental permit"while in the Omnibus Law Article 76 paragraph (1) states: "The Central Government or Regional Government applies administrative sanctions to the person in charge of the business and/or activity if during the supervision it is found a violation of the Business Licensing or Government Approval", where environmental permits are no longer an essential factor in administrative sanctions for actions that may be carried out by corporations, besides that there is potential for confusion over the subjects given authority by law wherein the scenario of administrative sanctions imposed by local governments, the central government has the authority to determine total executives have the possibility to intervene by higher authorities.

3. The disappearance of the strict liability concept contained in the law on environmental protection and management, in Article 88 of the environmental protection and management law related to proof of action stating: "Every person whose actions, business, and/or activities use hazardous materials and toxic, produces and/or manages hazardous and toxic materials, and/or which poses a serious threat to the environment, is absolutely responsible for the losses that occur without the need for proving the element of guilt", while Article 88 of the
Omnibus Law states "Anyone whose actions, its business, and/or activities use hazardous and toxic materials, produce and/or manage waste of hazardous and toxic materials, and/or those that pose a serious threat to the Environment, are absolutely responsible for the losses that occur from their business and/or activities. without the need for proof" in the Omnibus Law Article This implies the return of liability based on fault which is unable to anticipate activities risk large such as the law on environmental protection and management, which categorises activities carried out that endanger the Environment activities ultrahazardous so that based on the law on environmental protection and management, the person is obliged to bear any loss/damage arising from its activities.

The loss of strict liability in the responsibility for environmental destruction that occurs due to the implementation of the Omnibus Law is the implication of a setback in handling environmental crimes in Indonesia. This also distances Indonesia from applying the ecocide legal concept, which pivots on the nature of strict liability proposed by Higgins.

\subsection{Ecocides and river pollution by palm oil companies}

Several types of palm oil industry waste are responsible for water pollution; POME comes from the sterilisation process and clarification in palm oil mills. This waste should be processed first before finally being discharged into the environment because the composition itself contains a lot of acid, temperature, Biological Oxygen Demand, and Chemical Oxygen Demand when released into the POME environment, which is composed of $3-4 \%$ solid elements, and $0.5 \%$ solids. $2 \%$ of oil will directly pollute clean water as a source of community livelihood. The palm oil industry is estimated to produce 2.5 tons of effluent or about 0.5 tons of effluent per 1 tonne of the fresh palm fruit. This is a concern because the acidic effluent will endanger the water ecosystem where the waste will change the Power of Hydrogen; the water is relatively more acidic, which causes eutrophication in which algae will thrive the surface of the water. In addition, the fuel used in the production process is also found in the discharged waste, which will affect the microbial cycle in the water. Plus, herbicides and dangerous pesticides such as paraquat are hazardous for humans and water around the industrial area.

From data submitted by the Indonesian Forum for the Environment, it is known that 4,389,757 hectares of peat ecosystem were directly damaged by as many as 291 companies, consisting of 193 palm oil companies, until 2016 the Ministry of Environment and Forestry of the Republic of Indonesia has reached $6,772,633$ hectares of 702 plantation companies dominated by palm oil, (3) Policy loopholes in many regional executive reports of the Indonesian Forum for the Environment have also found many Palm Oil Entrepreneurs Groups operating in the area forests, by exploiting loopholes in the Land Policy for Agrarian Reform and Presidential Regulation No. 88 of 2017, by exploiting fictitious planters as owners of oil palm plantations. Land Policy Objects for Agrarian Reform from forest areas are still in the name of the people to protect the interests of oil palm plantations; Palm oil corporations also often take advantage of loopholes in Law No. 41 of 1999 in conjunction with Law No. 18 of 2013 to boost the rate of releasing forest areas and issuing permits.

To date, 859 palm oil corporations have been operating in forest areas. Many policies that provide space for corporations, 
not including the various privileges drafted in the Palm Oil Bill, which are said to be a temporary policy, actually perpetuate the practice of violating human rights and the Environment and destroying forests destroying animals and plants. Endemic, which is the wealth of the archipelago that should be protected. The policy ignores the facts of environmental and humanitarian crimes that oil palm plantations have committed for a century. Some wounds have never been healed from the practice of land grabbing, human rights violations, environmental pollution and forest destruction suffered by indigenous peoples/local communities, farmers, women and children.

This policy predicts an outdated and fragile economic model like palm oil, especially with an approach that is no less old school, namely natural resources for export as much as possible, while for domestic needs it is imported. This is the old paradigm of development that it is time to leave if you do not want the Indonesian economy to go bankrupt. What should be encouraged and voiced is corrective policies to improve the governance of our natural resources. However, it is impossible to improve governance if it does not start with the palm oil moratorium, whose policy draft is now on the President's desk. The palm oil moratorium must also be accompanied by environmental audits, review of permits and even revocation of permits for palm oil companies that violate laws and regulations. Some cases of environmental crimes committed by palm oil companies in Indonesia will be described in the following:

\subsubsection{Pollution of the Sambas River, Sambas Regency, West Kalimantan}

Cases of river water pollution due to the palm oil industry can be observed in Semana Village, which is located on the banks of the Sambas River. Around the area, as much as 280 ha of land is owned by an oil palm company, namely PT. Agro Nusa Investama (ANI), a subsidiary of Wilmar International and PT. Wana Hijau Semesta (WHS), a subsidiary of the Duta Palma group. Oil palm plantations in the area started about 25 years ago, and fishers have begun to worry about the decline in fish populations caused by water pollution. According to Asmadi (60 years old) stated that the availability of caught fish had decreased compared to before there was an oil palm industry in the area; as a reference in the past, oil palm fishers caught up to hundreds of kilograms of fish, and now fishers can only catch 4-10 Kg in one day. Every year between May and July, there is a large scale of fish deaths, starting with a change in the colour of the river to a bluish-green. Residents then took the dead fish; it turned out that after processing, the fish had a sour and bitter taste which affected stomach pain. According to the head of the Environmental Management Agency of Sambas Regency, the death of fish in the Sambas river was caused by palm oil waste from the processing of crude palm oil that entered the river. An investigation has been carried out to prove whether the company violated the waste disposal regulations that violate regulations, but so far, there has been no decision or sanction from the district government against the company.

Observations were also made to find that PT Agro Nusa Investama, as a subsidiary of Wilmar, still uses glyphosate and paraquat in its weed control efforts in plantations even though their use has been banned in many countries due to their level of toxicity. This is interesting because the Roundtable of Sustainable Palm Oil (RSPO), which Wilmar is a member of, has banned the use of paraquat in all of its member oil palm plantations. In a follow-up report, Wilmar claims that it has discontinued the use of paraquat on all of its plantations since 2011, but previous field findings contradict that claim.

\subsubsection{Pollution of the Rokan River, Riau}

The Rokan River is one of the largest rivers in Riau Province, which has about $350 \mathrm{~km}$ (upstream in the Bukit Barisan and empties into the sea waters of Rokan Hilir Regency) passes through Rokan Hulu Regency and Rokan Hilir Regency. The Rokan River flows through plantation areas and the palm and rubber industries as well as residential areas. Badran et al. Declare that the local palm oil industry has a production capacity of Crude Palm Oil (CPO) amounting to 700 tons/day, but only 400 tonnes of Fresh Fruit Bunch per day were realised with the capacity of the waste produced an average of $200 \mathrm{~m}^{3} /$ day. The palm oil industrial waste is channelled along $560 \mathrm{~m}$ into the Rokan river; the parameters assessed are Power of Hydrogen, Chemical Oxygen Demand, Biological Oxygen Demand, Total Suspended Solid, and Oil $\&$ Fat content which is compared with the reference of the Minister of Environment Regulation No. 5 of 2014 Appendix III [36].

The content of Chemical Oxygen Demand, Biochemical Oxygen Demand, Total Suspended Solid, and Rokan River Oil and Fat exceeds the Minister of Environment Regulation No. 5 of 2014 Appendix III's limit in all parameters. The acidity level of the Rokan River water itself tends to be acidic, which is a strong indicator of water pollution by palm oil waste which can come from palm oil waste, especially POME.

\subsubsection{Pollution of the Mahap River, Sekadau Regency, West Kalimantan}

The Map River, located in Sekadau Regency, West Kalimantan, is used by the surrounding community for their daily needs, including bathing, washing, cooking, and drinking. In 2007 an analysis was carried out to examine the water quality of the Mahap River, and the water quality was categorised as good because based on Government Regulation no. 82 of 2001, no test parameter exceeds the limit. In 2009 land clearing for oil palm plantations increased the risk of flooding and water quality degradation. As an illustration, the area of Nanga Mahap Village is designated chiefly as mixed plantations with an area of $890.44 \mathrm{Ha}$, settlements covering an area of $103.15 \mathrm{Ha}$, and the rest is used for farming. Irrigated and rainfed rice fields.

Standard water parameters that exceed the limit as determined by Government Regulation No. 82 of 2001, both for data taken in the dry season and rainy season. Biological Oxygen Demand and Chemical Oxygen Demand in the Mahap River in both seasons exceed the threshold; the high value of Biological Oxygen Demand and Chemical Oxygen Demand in the Mahap River indicates pollution. Although the total Suspended Solid shows no indication of exceeding the threshold, the Power of Hydrogen parameter tends to be acid. This has implications for acidic and corrosive water, resulting in metal toxicity and the continuity of the nitrification process. One of the causes of these parameters exceeding the threshold set based on the class 1 quality standard of Government Regulation No. 82 of 2001 is the existence of oil palm plantations in the upper Mahap River, as it is known that oil palm POME can change the nature of acidity, Biological Oxygen Demand, and Chemical Oxygen Demand. This study states that the decline in water quality in the Mahap River began when the palm oil industry was established in the local 
area; this proves that the palm oil industry hurts the Environment, especially river pollution.

There are three main reasons for incorporating environmental concerns as an extraordinary crime of ecocide into serious human rights violations, especially those committed by several palm oil companies in Indonesia:

a. That the quality of the Environment is the essence of human life that complements human dignity. This includes protecting civil and political rights and the fulfilment of economic, social and cultural rights. Therefore extraordinary legal steps are needed to protect the dignity of every person and community group.

b. Placing environmental concerns and crimes in the tradition of extraordinary crimes is a response to the inability of environmental laws national and even international punish perpetrators of environmental crimes or ecocides in which the methods of destruction have exceeded the capabilities of available legal norms.

c. Humanitarian approach in concern for environmental damage caused by ecocide crime will be more precisely to ensure restitution, rehabilitation and compensation to all victims of ecocide crime.

The year 2021 is the right momentum to immediately submit a proposal for ecocide to become the third crime as an extraordinary crime to be recognised in Law 26 of 2000 on Human Rights Courts.

\section{CONCLUSIONS}

The codification of ecocide as an international crime became a hot topic, in 2010 mainly by a lawyer from Scotland, Polly Higgins, who submitted an amendment to the Rome Statute to the International Law Commission, which included ecocide, which was defined as: "the extensive damage to, destruction of , or loss of ecosystem(s) of a given territory, whether by human agency or by other causes, to such an extent that peaceful enjoyment by the inhabitants of that territory has been or will be severely diminished". Environmental law in Indonesia does not include ecocide to describe criminal acts that damage the Environment, a term to express such acts known as environmental crimes or environmental offences. The loss of strict liability in the responsibility for environmental destruction that occurs due to the implementation of the Omnibus Law is the implication of a setback in handling environmental crimes in Indonesia.

Ecocides as a gross violation of human rights through a case study of river pollution by palm oil companies in Indonesia that there are three examples of environmental crimes committed by palm oil companies in Indonesia, for example, Pollution of the Sambas River, Sambas Regency, West Kalimantan; Pollution of the Rokan River, Riau; and Pollution of the Mahap River, Sekadau Regency, West Kalimantan. There are three main reasons for incorporating environmental concerns as an extraordinary crime of ecocide into serious human rights violations, especially those committed by several palm oil companies in Indonesia, namely: the quality of the Environment is the essence of human life that complements human dignity; environmental concerns and crimes in the tradition of extraordinary crimes are a response to the inability of national and even international environmental laws; and ensure restitution, rehabilitation and compensation to all victims of ecocide crime.

Based on the conclusions above, this research implies that it can be used as a basis for countries, especially Indonesia, to include ecocides as a serious violation of human rights and implement them through strict law enforcement and in favour of environmental conservation. It takes a common awareness of the government and lawmakers to respond to this very sad environmental damage. In addition, the community, in general, must strengthen supervision of environmental management activities; this is the first step and is considered effective in preventing the occurrence of ecocides in Indonesia.

\section{ACKNOWLEDGMENT}

We give our gratitude to Universitas Diponegoro for supporting this research.

\section{REFERENCES}

[1] Savilaakso, S., Garcia, C., Garcia-Ulloa, J., Ghazoul, J., Groom, M., Guariguata, M.R., Zrust, M. (2014). Systematic review of effects on biodiversity from oil palm production. Environmental Evidence, 3(1): 1-21. https://doi.org/10.1186/2047-2382-3-4

[2] Manning, F.C., Kho, L.K., Hill, T.C., Cornulier, T., Teh, Y.A. (2019). Carbon emissions from oil palm plantations on peat soil. Frontiers in Forests and Global Change, 2: 37. https://doi.org/10.3389/ffgc.2019.00037

[3] Darras, K.F., Corre, M.D., Formaglio, G., et al. (2019). Reducing fertilizer and avoiding herbicides in oil palm plantations-ecological and economic valuations. Frontiers in Forests and Global Change, 2: 65. https://doi.org/10.3389/ffgc.2019.00065

[4] Larsen, R.K., Gill, T. (2012). The Oil Palm Sector: Community Grievances and Water Governance in Central Kalimantan, Indonesia. SEI Policy Brief.

[5] Balogh, J.M., Jámbor, A. (2020). The environmental impacts of agricultural trade: A systematic literature $\begin{array}{lll}\text { review. } & \text { Sustainability, } & 1152 .\end{array}$ https://doi.org/10.3390/su12031152

[6] Lubchenco, J. (1998). Entering the century of the environment: a new social contract for science. Science, 279(5350):

491-497. https://doi.org/10.1126/science.279.5350.491

[7] Saleh, M.R. (2021). Ecological Disaster Gets Worse, Ecocide Proposal Momentum. Mangobay. https://www.mongabay.co.id/2021/01/25/bencanaekolo gis-makin-parah-momentum-proposal-ekosida/.

[8] Goodland, R. (2012). Responsible mining: the key to profitable resource development. Sustainability, 4(9): 2099-2126. https://doi.org/10.3390/su4092099

[9] Dang, A.N., Jackson, B.M., Benavidez, R., Tomscha, S.A. (2021). Review of ecosystem service assessments: Pathways for policy integration in Southeast Asia. Ecosystem $\quad$ Services, 49: 101266. https://doi.org/10.1016/j.ecoser.2021.101266

[10] Higgins, P., Short, D., South, N. (2013). Protecting the planet: A proposal for a law of ecocide. Crime, Law and Social Change, 59(3): 251-266. https://doi.org/10.1007/s10611-013-9413-6

[11] Crook, M., Short, D. (2014). Marx, Lemkin and the genocide-ecocide nexus. The International Journal of Human Rights, 18(3): 298-319. https://doi.org/10.1080/13642987.2014.914703 
[12] Lindgren, T. (2018). Ecocide, genocide and the disregard of alternative life-systems. The International Journal of Human Rights, 22(4): 525-549. https://doi.org/10.1080/13642987.2017.1397631

[13] Prakasa, S.U.W. (2021). Ecocide crimes \& omnibus law: review of international law and its implications on Indonesia law. Dinamika Hak Asasi Manusia, 12(2): 1420. https://doi.org/10.24123/jdh.v12i2.2898

[14] Koivurova, T. (2014). Introduction to International Environmental Law. Abingdon, Oxon: Routledge.

[15] Pereira, J.C. (2015). Environmental issues and international relations, a new global (dis) order-the role of International Relations in promoting a concerted international system. Revista Brasileira de Política Internacional, $\quad 58$ : 191-209. https://doi.org/10.1590/0034-7329201500110

[16] McDermott, Y., Schabas, W.A. (2016). Creating a framework for the prosecution of environmental crimes in International Criminal Law. In The Ashgate Research Companion to International Criminal Law, 90-108. https://doi.org/10.4324/9781315613062-9

[17] Dunlap, A. (2018). The 'solution'is now the 'problem:'wind energy, colonisation and the 'genocideecocide nexus' in the Isthmus of Tehuantepec, Oaxaca. The International Journal of Human Rights, 22(4): 550573. https://doi.org/10.1080/13642987.2017.1397633

[18] Leal Filho, W., Azul, A.M., Brandli, L., Lange Salvia, A., Wall, T. (2021). Life on Land. Cham: Springer International Publishing, https://doi.org/10.1007/978-3319-95981-8

[19] Priestley, C. (2021). We won't survive in a city. The marshes are our life: An analysis of ecologically induced genocide in the Iraqi Marshes. Journal of Genocide Research, 23(2): 279-301. https://doi.org/10.1080/14623528.2020.1792615

[20] Greene, A. (2018). The campaign to make ecocide an international crime: quixotic quest or moral imperative. Fordham Envtl. L. Rev., 30(3): 1-48.

[21] Braithwaite, J. (1982). Enforced self-regulation: A new strategy for corporate crime control. Michigan Law Review, 80(7): 1466-1507. https://doi.org/10.2307/1288556

[22] McDonnell-Elmetri, Z. (2020). The crime of ecocide: the answer to our environmental emergency. University of Otago, New Zealand, 2020.

[23] Colangelo, A.J., Hayes, P. (2019). An international tribunal for the use of nuclear weapons. Journal for Peace and Nuclear Disarmament, 2(1): 219-252. https://doi.org/10.1080/25751654.2019.1624248

[24] Lara, B. (2015). The failure of environmental international law during times of war. University of Baltimore Journal of Land and Development, 4(2): 141164. https://scholarworks.law.ubalt.edu/ubjld/vol4/iss2/3.

[25] Kaleck, W., Ratner, M., Singelnstein, T., Weiss, P. (2006). International Prosecution of Human Rights Crimes. Springer Science \& Business Media. Berlin Heidelberg New York: Springer.
[26] Adelman, S. (2015). Tropical forests and climate change: a critique of green governmentality. International Journal of Law in Context, 11(2): 195-212. https://doi.org/10.1017/S1744552315000075

[27] Alonso-Fradejas, A. (2021). 'Leaving no one unscathed' in sustainability transitions: The life purging agroextractivism of corporate renewables. Journal of Rural Studies, 81 : 127-138. https://doi.org/10.1016/j.jrurstud.2020.10.001

[28] Wibisana, A.G., Faure, M.G., Majory, R. (2021). Error in Personam: Confusion in Indonesia's environmental corporate criminal liability. In Criminal Law Forum, 32(2): 247-284. https://doi.org/10.1007/s10609-02109412-6

[29] de La Cuesta, J.L. (2013). Criminal responsibility of legal persons in Spanish law. Revue Internationale de Droit Pénal, 84(1): 143-179. https://doi.org/10.3917/ridp.841.0141

[30] Januarsyah, M.P.Z., Astawa, I.G.P., Atmasasmita, R., Gultom, E. (2020). The idea of implementing a deferred prosecution agreement with the anti-bribery management system in corruption crime management by corporations in Indonesia. International Journal of Criminology and Sociology, 9: 1379-1384. https://doi.org/10.6000/19294409.2020.09.158

[31] Shover, N. (2003). Corporate crime, law, and social control. Contemporary Sociology, 32(4): 500. https://doi.org/10.2307/1556590

[32] Varkkey, H., Tyson, A., Choiruzzad, S.A.B. (2018). Palm oil intensification and expansion in Indonesia and Malaysia: Environmental and socio-political factors influencing policy. Forest Policy and Economics, 92: 148-159. https://doi.org/10.1016/j.forpol.2018.05.002

[33] Angga, L.O., Akyuwen, R.J., Laturette, A.I., Daties, D.R.A., Tuhulele, P., Labetubun, M.A.H., Taufik, I. (2021). Responsibilities of industry actors to environmental conservation in coastal areas. International Journal of Sustainable Development and Planning, 16(4): 651-660. https://doi.org/10.18280/ijsdp.160405

[34] Salam, S., Parawansa, S.S.R., Mursanto, D., Karim, L. M., Ernawati, L., Rahail, E.B., Raf, N. (2019). Corporate legal responsibility against environmental damage. In IOP Conference Series: Earth and Environmental Science, 343(1): 012137. https://doi.org/10.1088/17551315/343/1/012137

[35] Rela, I.Z., Awang, A.H., Ramli, Z., Md Sum, S., Meisanti, M. (2020). Effects of environmental corporate social responsibility on environmental well - being perception and the mediation role of community resilience. Corporate Social Responsibility and Environmental Management, 27(5): 2176-2187. https://doi.org/10.1002/csr.1956

[36] Islam, M.M., Islam, M.A. (2021). The impact of anthropogenic and environmental factors on the variability of Escherichia coli in rivers in southwest Bangladesh. In Review, Preprint. https://doi.org/10.21203/rs.3.rs-901563/v1 